\title{
Review of the genus Eutetrarhynchus Pintner, 1913 (Trypanorhyncha: \\ Eutetrarhynchidae), with the description of Eutetrarhynchus beveridgei n. sp.
}

\author{
Bjoern C. Schaeffner
}

Received: 20 January 2014 / Accepted: 3 February 2014

\author{
B. C. Schaeffner $(\square)$ \\ Department of Veterinary Science, The University of Melbourne, Veterinary Clinical Centre, \\ 250 Princes Highway, Werribee, Victoria 3030, Australia \\ e-mail: b.schaeffner@unimelb.edu.au
}

\begin{abstract}
The genus Eutetrarhynchus Pintner, 1913 is revised. Eutetrarhynchus beveridgei n. sp. is described from the spiral intestine of the dwarf whipray, Himantura walga (Müller \& Henle) (Myliobatiformes: Dasyatidae), from the South China Sea off the Malaysian part of Borneo. The new species is characterised by a slender, elongate scolex, two oval bothria, muscular bulbs, retractor muscles inserting at the base of the bulbs, and the presence of glandcells and prebulbar organs. The tentacular armature is typical heteroacanthous with heteromorphous hooks. Eutetrarhynchus beveridgei n. sp. is allocated to the genus due to its distinct segment morphology featuring two internal seminal vesicles and scattered testes occupying the complete intervascular space. It differs from congeners in its relatively small size, much smaller scolex regions and in the presence of a basal armature with a distinct basal swelling. Eutetrarhynchus cortezensis Friggens \& Duszynski, 2005 is transferred to Dollfusiella Campbell \& Beveridge, 1994, as D. cortezensis n. comb., on the basis of its segment morphology, with testes in a linear arrangement and the absence of internal seminal vesicles. A new generic diagnosis and a key for the identification of species of Eutetrarhynchus is provided.
\end{abstract}

\section{Introduction}


The genus Eutetrarhynchus Pintner, 1913 was erected by Pintner (1913) to accommodate two species, Eutetrarhynchus ruficollis (Eysenhardt, 1829) Pintner, 1913 (type-species) and E. leucomelanus (Shipley \& Hornell, 1906) Pintner, 1913.

He (1913) defined the genus as having a slender, elongate scolex with two bothria, elongate, muscular bulbs, retractor muscles inserting at the base of each bulb, a craspedote strobila, numerous, scattered testes occupying the complete intervascular space, genital pores near the mid-line of the segments and tentacles with numerous, homeomorphous hooks. Dollfus (1942) re-defined the genus and added two species, Eutetrarhynchus carayoni Dollfus, 1942 and E. lineatus (Linton, 1908). In a more recent generic diagnosis presented by Campbell \& Beveridge (1994), species of Eutetrarhynchus were characterised by a typical heteroacanthous armature with homeo- or heteromorphous, hollow hooks, the absence of both a basal swelling and distinct basal armature and the possession of either a craspedote or acraspedote strobila. This definition separated the species of Eutetrarhynchus from the newly-erected genus Dollfusiella Campbell \& Beveridge, 1994 (see Campbell \& Beveridge, 1994). Many species were transferred into the closely related genus Dollfusiella (see Campbell \& Beveridge, 1994; Beveridge \& Jones, 2000; Beveridge et al., 2004). However, the taxonomic allocation of species to either of these genera is complicated due to morphological similarities. Recently, two novel species were described in Eutetrarhynchus, E. platycephali Palm, 2004 and E. cortezensis Friggens \& Duszynski 2005, which increased the number of taxa to four species (Palm, 2004; Friggens \& Duszynski, 2005). However, the four representatives show striking differences in their segment morphology, thus, a combination of species of different genera is most likely.

In the present study a new species of Eutetrarhynchus is described from material from a species of dasyatid ray collected off the Malaysian part of Borneo. The new species is characterised by a combination of morphological features, which closely reflect those of the type-species of Eutetrarhynchus. Hence, it is now possible to provide a new morphological diagnosis of the genus. Overall, Eutetrarhynchus is revised and a key for the identification of species is provided.

\section{Materials and methods}

Cestodes used in the present study were collected from the spiral intestines of several specimens of the dwarf whipray Himantura walga (Müller \& Henle) which were obtained from two sampling localities in the Malaysian part of Borneo. 
Worms were processed for morphological study as described by Schaeffner et al. (2011). Line drawings of tentacles and mounted specimens were made using an Olympus BH-2 microscope with a drawing attachment tube and Nomarski interference contrast optics. Morphological characteristics in the species description follow the terminology of Pintner (1913), Dollfus (1942) and Campbell \& Beveridge (1994). Microthrix terminology follows Chervy (2009). Measurements are in micrometres, unless otherwise indicated, and are given as the range followed by the mean, standard deviation and the number of features measured in parentheses. Individual measurements are presented, if the number of measurements for this character was less than three. Due to the small size of tentacles and tentacular hooks, the measurements of the oncotaxy were obtained directly from line drawings. Vitelline follicles are circummedullar and are illustrated on the lateral margins of segments only. One specimen was selected for scanning electron microscopy (SEM) and processed as described in Schaeffner et al. (2011). Scanning electron micrographs were taken using a Hitachi S-570 scanning electron microscope (Hitachi Ltd.). Specimens were deposited in the helminthological collections of the Muzium Zoologi, University of Malaya, Institute of Biological Sciences, Kuala Lumpur, Malaysia (MZUM) and the Lawrence R. Penner Parasitology Collection, Department of Ecology and Evolutionary Biology, University of Connecticut, Storrs, Connecticut, USA (LRP). Host classification follows Last et al. (2010). Information on individual host records and sampling localities from Malaysian Borneo (accession record BO) is available from the Global Cestode Database (Caira et al., 2012).

\section{Eutetrarhynchus beveridgei n. sp.}

Type-host: Himantura walga (Müller \& Henle) (Myliobatiformes: Dasyatidae) (accession nos.: BO-162, BO-30, BO-141, BO-238).

Type-locality: South China Sea off Sematan, Sarawak, Malaysia (01 $\left.48^{\prime} \mathrm{N}, 1^{\circ} 9^{\circ} 46^{\prime} \mathrm{E}\right)$.

Additional localities: South China Sea off Mukah, Sarawak, Malaysia (02 $\left.53^{\prime} \mathrm{N}, 112^{\circ} 05^{\prime} \mathrm{E}\right)$.

Site of infection: Spiral intestine.

Prevalence: c. $10 \%$ (of all $\mathrm{H}$. walga dissected).

Intensity: 1-2 specimens.

Host specificity: Oioxenous (rank $=1$, index $=0.0$; sensu Caira et al., 2003).

Type material: Holotype in MZUM (No. 2014.1(H)). Paratypes in LRP (Nos. 8392-8394). Serial sections in LRP (Nos. 8395-8407). 
Etymology: This species is named in honour of Professor Ian Beveridge for his major contributions to the knowledge and systematics of trypanorhynch cestodes.

\section{Description (Figs. 1-3)}

[Based on 4 whole-mounts, 1 specimen used for SEM and serial sectioning.] Cestodes 7.2-11.0 $(9.3 \pm 1.9 ; \mathrm{n}=3) \mathrm{mm}$ long (Fig. 1F), with 27-31 (29 $\pm 2 ; \mathrm{n}=3)$ segments in mature strobilae (Fig. 1F); strobila with $20(\mathrm{n}=1)$ immature segments; gravid specimen $22.9(\mathrm{n}=1) \mathrm{mm}$ long (Fig. 1F), with $29(\mathrm{n}=1)$ segments, posteriormost segment gravid. Scolex acraspedote (Figs. 1A, F, 3A), slender, elongate, 1,890-2,850 (2,252 $\pm 427 ; \mathrm{n}=4)$ long; maximum width at level of pars bothrialis, 305-350 (335 $\pm 26 ; \mathrm{n}=3)$ wide; pars bothrialis 190-240 (213 $\pm 22 ; \mathrm{n}=4)$ long (Figs. 1A, C, 3A, B); bothria 2, oval, 240-260 ( $\mathrm{n}=2)$ long by $235(\mathrm{n}=2)$ wide, with free posterior margins, with thick, fleshy margins (Figs. 1A, C, 3A, B); distal bothrial surface covered with capilliform filitriches; proximal bothrial surface covered with palmate spinitriches and acicular filitriches (Fig. 3C); bothrial pits absent; pars vaginalis longer than pars bothrialis (Figs. 1A), 890-1,850 (1,243 $\pm 423 ; n=4)$ long by 180-220 (183 $\pm 39 ; n=4)$ wide, covered with palmate spinitriches and acicular filitriches (Fig. 3D); tentacle sheaths sinuous (Fig. 1A); pars bulbosa 950-1,020 (983 $\pm 29 ; \mathrm{n}=4)$ long by 190-270 (233 $\pm 39 ; \mathrm{n}=4)$ wide; prebulbar organs present (Fig. 1A, B); bulbs slender, elongate (Fig. 1A, B), 940-1,050 (978 \pm 31 ; n = 12) long by $85-120(100 \pm 12 ; \mathrm{n}=12)$ wide; bulb width/length ratio $1.0: 8.1-11.7(1.0: 9.9 \pm 1.3 ; \mathrm{n}$ $=12$ ); retractor muscle originates at base of bulb (Fig. 1B); gland-cells present, reach in anterior part of bulb (Fig. 1A, B); pars post-bulbosa short (Fig. 1A), 20-50 (28 $\pm 15 ; \mathrm{n}=4$ ) long; scolex ratio (pars bothrialis : pars vaginalis : pars bulbosa) $1.0: 4.5-8.4: 4.3-5.0$ (1.0 : $5.8 \pm 1.8: 4.7 \pm$ $0.4 ; \mathrm{n}=4)$.

Fully everted tentacle $950(\mathrm{n}=1)$ long; tentacle diameter 30-33 $(32 \pm 1 ; \mathrm{n}=4)$ at base, 45-49 (47 $\pm 2 ; n=4)$ at basal swelling (Fig. 2A, C), 38-43 $(41 \pm 2 ; n=7)$ in metabasal region (Fig. 2B), 35-40 (38 $\pm 2 ; n=5)$ in distal region. Metabasal armature heteroacanthous, heteromorphous (Figs. 2B, 3F-I); hooks hollow, in ascending half spiral rows. Hook files begin on antibothrial surface of tentacle (Fig. 3G), terminate on bothrial surface (Figs. 2B, 3I, J); 21 hooks per principle row; hook files 1 and 1' not separated (Fig. 3J). Hook files 1(1')-4(4') falcate (Fig. 3G), 9-11 (10 $\pm 1 ; \mathrm{n}=15)$ long, base elongate, 3-8 (6 $\pm 1 ; \mathrm{n}=15)$ long; hook files 5(5')10(10') falcate (Fig. 3G), 7-10 (9 $\pm 1 ; n=25)$ long, base not elongate, $2-3(2 \pm 1 ; n=25)$ long; hook files 11(11')-14(14') falcate, with recurved tips (Figs. 2B, 3F, H), 7-10 (9 $\pm 1 ; n=10)$ long, base 1-2 (2; $\mathrm{n}=10)$ long; hook files 15(15')-16(16') falcate (Figs. 2B, 3I), larger, 11-14 $(12 \pm 1 ; \mathrm{n}=25)$ long, base $1-2(1 ; \mathrm{n}=25)$ long; hook files $17\left(17^{\prime}\right)-18\left(18^{\prime}\right)$ falcate, $11-12(11 \pm$ 
1; $\mathrm{n}=25)$ long, base elongate (Figs. 2B, 3I, J), 5-8 (7 \pm 1 ; $\mathrm{n}=25)$ long; hook files 19(19')21(21') uncinate (Figs. 2B, 3I, J), 7-10 (9 $\pm 1 ; n=25)$ long, base 5-7 (6 $\pm 1 ; n=25)$ long.

Distinctive basal armature present (Figs. 2A, C, 3E); first row of basal hooks uncinate (Fig. 2A, C), 6-10 (8 1 ; $\mathrm{n}=10)$ long, base 3-5 (4 $\pm 1 ; \mathrm{n}=10)$ long; next 4 rows of basal hooks falcate (Fig. 2A, C), 8-10 (9 $\pm 1 ; \mathrm{n}=25)$ long, base $1-4(2 \pm 1 ; \mathrm{n}=25)$ long; basal swelling present (Figs. 2A, C, 3E), with 12-14 rows of hooks; hooks on antibothrial surface falcate (Figs. 2A, C, 3E), with recurved tips, 5-7 (5 $\pm 1 ; \mathrm{n}=10)$ long, base $1-2(2 ; \mathrm{n}=10)$ long; hooks become uncinate with broad bases towards internal and external surfaces (Fig. 2A, C), 3-6 (4 \pm $1 ; \mathrm{n}=25)$ long, base 3-4 ( $3 \pm 1 ; \mathrm{n}=25)$ long; hooks become falcate towards bothrial surface (Fig. 2A, C), 4-7 (6 $\pm 1 ; \mathrm{n}=25)$ long, base $1-2(1 ; \mathrm{n}=25)$ long. Principle hook rows begin at level of row 21 (Fig. 2A).

Segments acraspedote (Figs. 1A, F, 3A); first immature segments 25-50 (33 \pm 12 ; n = 4) long by 95-160 (124 $\pm 27 ; \mathrm{n}=4)$ wide; first mature segments 390-620 (483 $\pm 121 ; \mathrm{n}=3)$ long by $220-250(227 \pm 21 ; n=3)$ wide; terminal mature segments $2,670(n=1)$ long by $360(n=1)$ wide. Genital pores in posterior third of segment (Fig. 1E); pore inconspicuous; cirrus sac elongate to ovoid (Fig. 1D, E), 93-118 ( $n=2)$ long by $180(n=2)$ wide; cirrus unarmed; two internal seminal vesicles present (Fig. 1D, E); external seminal vesicle absent (Fig. 1D, E). Vas deferens coils posteriorly towards ovarian isthmus (Fig. 1E). Testes occupy complete intervascular space (Fig. 1E), in 2-3 layers, exclusively preovarian (Fig. 1E), 90-105 (96 \pm 5; n = 15) long by 60-75 (68 $\pm 4 ; \mathrm{n}=15)$ wide; total number of testes 69-90 (84 $\pm 4 ; \mathrm{n}=7)$, with 58$75(70 \pm 5 ; \mathrm{n}=7)$ preporal, $12-15(13 \pm 2 ; \mathrm{n}=7)$ postporal. Vagina enters genital atrium posterior to cirrus-sac (Fig. 1D, E), with enlarged vaginal sphincter at posterior boundary of cirrus-sac (Fig. 1D, E), 100-130 $(112 \pm 16 ; \mathrm{n}=3)$ in diameter; vagina $c .13(\mathrm{n}=1)$ wide within vaginal sphincter, runs posteriorly to ovarian isthmus (Fig. 1E); seminal receptacle absent. Ovary at posterior margin of segment (Fig. 1E), bilobed in dorso-ventral view (Fig. 1E); ovarian lobes 315-323 $(313 \pm 10 ; \mathrm{n}=3)$ long by 78-95 $(83 \pm 11 ; \mathrm{n}=3)$ wide in mature segments, $430-488$ $(453 \pm 30 ; \mathrm{n}=3)$ long by $85-113(96 \pm 15 ; \mathrm{n}=3)$ wide in late mature segments. Mehlis' gland between posterior parts of ovarian lobes (Fig. 1E), 118-130 $(122 \pm 7 ; n=3)$ in diameter in mature segments, $180(\mathrm{n}=2)$ in late mature segments. Vitelline follicles circummedullar, 35-50 $(42 \pm 5 ; n=15)$ in diameter. Uterus median (Fig. 1E), tubular, simple, extending between rows of testes to anterior extremity of segment; uterine pore absent.

\section{Remarks}


The present specimens are characterised by a slender, elongate and acraspedote scolex, large tentacular bulbs with internal gland-cells, the presence of prebulbar organs and enlarged microtriches covering the whole scolex peduncle. The metabasal tentacular armature is typical heteroacanthous, with 21 heteromorphous hooks per principle row. The basal armature is distinctive, with a basal swelling incorporating several types of hooks of different shapes and sizes. The presence of two internal seminal vesicles and numerous testes occupying the complete intervascular space allocates this species to the genus Eutetrarhynchus. It closely resembles the type-species, E. ruficollis, in its possession of (i) two internal seminal vesicles; (ii) a vaginal sphincter; (iii) enlarged microtriches covering the scolex peduncle; and (iv) heteromorphous tentacular hooks. However, the present specimens differ from the type-species in (i) different scolex proportions; (ii) a much smaller scolex (2.3 vs 10.0-15.0 mm, respectively); (iii) much smaller tentacular bulbs (978 vs 7,000-8,000, respectively); and (iv) a strobila with acraspedote segments. Both species are, thus, considered to represent congeners. The presence of both a basal swelling and a distinctive basal armature further distinguishes the present specimens from $E$. ruficollis as well as from all the remaining species, E. leucomelanus, E. platycephali and E. cortezensis. Eutetrarhynchus leucomelanus differs from the present specimens in its possession of (i) homeomorphous tentacular hooks; (ii) a strobila with craspedote segments; (iii) a much larger scolex (4.8-6.2 vs $2.3 \mathrm{~mm}$, respectively); (iv) much smaller tentacular bulbs (3,300-4,100 vs 978, respectively); (v) a single internal seminal vesicle; (vi) a powerfully developed musculature; and (vii) vitelline follicles arranged in longitudinal rows between bands of musculature (see Beveridge, 1990). Specimens described in the present study are differentiated from E. platycephali by (i) a smaller scolex (2.3 vs $3.3 \mathrm{~mm}$, respectively); (ii) smaller bulbs (978 vs 1,396, respectively); (iii) the presence of enlarged microtriches covering the entire scolex peduncle; and (iv) the absence of a single enlarged hook on the external tentacular surface. Eutetrarhynchus beveridgei $\mathrm{n}$. sp. is therefore considered to represent a morphologically distinct but closely related species.

The Malaysian specimens were collected from four host individuals of a single species of whipray, H. walga. Given the extensive sampling effort in both the Malaysian and the Indonesian parts of Borneo, conducted by Drs J. N. Caira and K. Jensen, a large number of elasmobranchs have been dissected, including numerous species of Himantura Müller \& Henle. However, only a single species was infected. Overall, 42 specimens of $H$. walga were dissected but only about ten percent were infected with a very small number of worms. The present specimens appear highly host specific (oioxenous), only infecting a single species of dasyatid host. Since they were found in relatively small numbers they are also considered to represent a 
very rare species with low infection rates, which might be due to their restricted adaptation to the single host species.

\section{Dollfusiella cortezensis (Friggens \& Duszynski, 2005) n. comb.}

Type-host: Urolophus halleri Cooper (Myliobatiformis: Urolophidae).

Type-locality: Puerto Peñasco, Sonora, Mexico $\left(31^{\circ} 18^{\prime} \mathrm{N}, 113^{\circ} 32^{\prime} \mathrm{W}\right)$.

Site of infection: Spiral intestine.

Remarks

Eutetrarhynchus cortezensis Friggens \& Duszynski (2005) was described based on specimens from the spiral intestines of urolophid rays collected off Mexico (Friggens \& Duszynski, 2005). The specimens were characterised by an acraspedote strobila and a typical heteroacanthous armature with heteromorphous hooks. However, E. cortezensis differs from the remaining species within Eutetrarhynchus in the presence of an external rather than an internal seminal vesicle and ten principle hooks per row in the metabasal tentacular armature. The most striking difference from congeners is the arrangement of testes in two longitudinal rows rather than scattered throughout the medulla. The general body morphology and oncotaxy of E. cortezensis most likely represents a species belonging to the related genus Dollfusiella. Friggens \& Duszynski (2005) also compared E. cortezensis with six species with enlarged microtriches covering the entire scolex peduncle. However, these authors were unaware that these representatives had been transfered to Dollfusiella earlier (see Beveridge \& Jones, 2000; Beveridge et al., 2004). Currently, a total of fifteen species of Dollfusiella were shown to possess enlarged, microscopically visible microtriches on the scolex (Schaeffner \& Beveridge, 2013). Following the key for the identification of species provided by Schaeffner \& Beveridge (2013), E. cortezensis resembles D. imparispinis Schaeffner \& Beveridge, 2013, D. aculeata Beveridge, Neifar \& Euzet, 2004 or D. ocallaghani (Beveridge, 1990) Beveridge \& Jones, 2000.

Eutetrarhynchus cortezensis differs from all of these species in the absence of a distinctive basal armature and/or a distinctive basal swelling (the description of E. cortezensis states that a small basal swelling is present although it is not clearly shown in the illustrations, see Friggens \& Duszynski, 2005). Furthermore, it differs from D. imparispinis in having larger bulbs (413 vs $264 \mu \mathrm{m}$, respectively), from $D$. aculeata in lacking slightly enlarged basal hooks and from $D$. ocallaghani in having smaller bulbs (413 vs $600 \mu \mathrm{m}$, respectively). Based on its segment 
morphology and patterns in oncotaxy, E. cortezensis is hereby transferred to Dollfusiella as D. cortezensis $\mathrm{n}$. comb., where it is considered to represent a distinct species.

\section{Genus Eutetrarhynchus Pintner, 1913}

\section{Diagnosis}

Eutetrarhynchidae Guiart, 1927. Scolex acraspedote, slender; maximum width at level of pars bothrialis. Two oval bothria with free posterior margins. Pars vaginalis longer than pars bothrialis; enlarged microtriches present or absent. Bulbs slender, elongate. Retractor muscle inserts at base of bulb. Prebulbar organs and gland-cells within bulbs present. Metabasal armature typical heteroacanthous; hooks homeomorphous or heteromorphous; hook files 1 and 1' not separated. Basal swelling and distinctive basal armature present or absent. Segments craspedote or acraspedote. Genital pores marginal, in mid-line or posterior third of segment; cirrus sac pyriform to ovoid; one crescentic or two internal seminal vesicles present (unknown for E. platycephali). Testes scattered, fill medulla, in several layers. Ovary at posterior extremity of segment. Vitelline follicles encircle medulla or arranged in longitudinal bands. Uterus median, tubular. Uterine pore absent. Parasitic in houndsharks (Carcharhiniformes: Triakidae), guitarfishes (Rajiformes: Rhinobatidae) and/or stingrays (Myliobatiformes: Dasyatidae). Typespecies: E. ruficollis (Eysenhardt, 1829) Pintner, 1913.

\section{Key to the species of Eutetrarhynchus}

This key is simplified and only the most obvious characteristics have been maintained. It is recommended to consult original descriptions and/or re-descriptions to confirm individual species identifications.

1 Scolex covered with enlarged, microscopically visible microtriches; metabasal tentacular armature with heteromorphous hooks

- Scolex not covered with enlarged microtriches; tentacular armature with homeomorphous hooks

2 Scolex more than $10 \mathrm{~mm}$ in length; bulbs between 7 and $8 \mathrm{~mm}$ in length; strobila with craspedote segments; tentacular armature without basal swelling and distinctive basal armature E. ruficollis (Eysenhardt, 1829) 
- Scolex less than $3 \mathrm{~mm}$ in length; bulbs about $1 \mathrm{~mm}$ in length; strobila with acraspedote segments; tentacular armature with basal swelling and distinctive basal armature

E. beveridgei n. sp.

3 Scolex between 2.7 and $4.1 \mathrm{~mm}$ in length; bulbs less than $2 \mathrm{~mm}$ in length; pars postbulbosa absent; strobila with acraspedote segments E. platycephali Palm, 2004

- Scolex between 4.8 and $6.2 \mathrm{~mm}$ in length; bulbs more than $3 \mathrm{~mm}$ in length; pars postbulbosa longer than $1.4 \mathrm{~mm}$; strobila with craspedote segments

E. leucomelanus (Shipley \& Hornell, 1906)

\section{Discussion}

The composition and number of species within the eutetrarhynchid genus Eutetrarhynchus has changed multiple times since its erection by Pintner (1913). Although Beveridge (1990) listed a total of 19 different species, there were in fact 21 valid taxa within Eutetrarhynchus, which represented the highest number of species ever belonging to this genus. The once relatively species-rich genus underwent transformation when Campbell \& Beveridge (1994) erected the closely-related genus Dollfusiella. These authors transferred two species, D. australis (Prudhoe, 1969), Campbell \& Beveridge, 1994 and D. carayoni (Dollfus, 1942) Campbell \& Beveridge, 1994. Subsequently, almost every representative within Eutetrarhynchus was allocated to Dollfusiella, overall 15 different species (Beveridge \& Jones, 2000; Beveridge et al., 2004). Two additional species have been placed into the closely related genera Paroncomegas Campbell, Marques \& Ivanov, 1999 [i.e. Pa. araya (Woodland, 1934) Campbell, Marques \& Ivanov, 1999] and Prochristianella Dollfus, 1946 [i.e. Pr. glabra (Dollfus, 1969) Palm, 2004] (see Campbell et al., 1999; Palm, 2004; respectively). Ultimately, from the 21 species classified within Eutetrarhynchus in 1990's, only two species remained, namely E. ruficollis and E. leucomelanus. Two species have recently been described, E. platycephali and E. cortezensis (see Palm, 2004; Friggens \& Duszynski, 2005, respectively), one of which has now been transferred into Dollfusiella, as D. cortezensis (see above).

Eutetrarhynchus platycephali represents the most poorly known species within the genus. It has been described on the basis of a single specimen collected from an unidentified species of flathead from Indonesia (Palm, 2004). The most important morphological characteristics to confidently allocate this species to Eutetrarhynchus, such as the configuration of the cirrus-sac or arrangement of testes, were unavailable because the sole specimen was a plerocercus. The oncotaxy of this specimen was inadequately described and line drawings of different tentacular 
surfaces were not provided. Palm (2004) provided photographs taken with a light microscope showing the complete plerocercus, tentacles and proximal parts of the tentacle sheath and scolex. These photographs, however, do not facilitate recognition of this species. Without any information on the segment morphology or detailed illustrations of the tentacular armature it is almost impossible to allocate the single specimen to a eutetrarhynchid or any other trypanorhynch genus.

Palm (2004) also mentioned but did not illustrate a slightly enlarged, single hook on the external tentacular surface. The presence of a single enlarged hook at the basal armature and more than 14 relatively homeomorphous hooks per principle row in the metabasal armature would allocate this specimen to the closely related genus Hispidorhynchus Schaeffner \& Beveridge, 2012. However, representatives of Hispidorhynchus possess an asymmetrical basal swelling and a single enlarged hook positioned on the bothrial surface (Schaeffner \& Beveridge, 2012b). In addition, a relationship to Dollfusiella or Tetrarhynchobothrium Diesing, 1854 cannot be excluded. Due to the lack of taxonomic information, a definitive allocation to Eutetrarhynchus could not be confirmed, making E. platycephali a potential species inquirenda.

However, Haseli et al. (2010) redescribed E. platycephali based on five mature worms collected from three elasmobranch species from the Persian Gulf. These specimens corresponded to the original description of the type-specimen in their metrical data of the scolex and the possession of a single, enlarged hook on the external tentacular surface. Although the mature segment was described for the first time, many morphological features were omitted, such as (i) the number and arrangement of testes; (ii) the presence or absence of internal seminal vesicles; (iii) the size and distribution of vitelline follicles; (iv) the size and position of the Mehlis' gland; (v) the course of the vagina; (vi) the course of the vas deferens; (vii) the number and metrical ranges of mature segments; and (viii) the presence or absence and composition of gravid segments (see Haseli et al., 2010). Furthermore, the tentacular armature was given relatively little attention and information on the origin and termination of principle rows and the number of principle hooks is missing (see Haseli et al., 2010). This species is tentatively retained within Eutetrarhynchus based only on the presence of scattered testes occupying the complete intervascular space. New material is necessary to provide a full morphological description of this species, with a special focus on the segment morphology, in particular the morphology of the cirrus sac.

The present study provides the description of a fourth species of Eutetrarhynchus, E. beveridgei. A new updated generic diagnosis is provided focusing on slightly different morphological characters (e.g. the arrangement of testes and composition of the cirrus sac) to combine the four species. Although the tentacular armature includes a combination of 
oncotaxological features, such as the presence or absence of a basal swelling or a distinctive basal armature, the composition and arrangement of internal organs inside the proglottid were regarded as more significant morphological characteristics to group these species taxonomically. Thereby, the definition of the genus was modified so that Eutetrarhynchus now includes species with either an acraspedote (i.e. E. beveridgei and E. platycephali) or craspedote strobila (i.e. E. ruficollis and E. leucomelanus). However, these morphological differences between congeners are not considered to be sufficient to warrant the erection of a new genus. Future studies might provide evidence for the erection of a separate but closely-related genus. Until then, more material for molecular studies is needed to clarify the taxonomic placement of E. beveridgei and the decisions made herein.

The discovery of E. beveridgei from the South China Sea represents the fiftieth trypanorhynch species collected from elasmobranchs off the island of Borneo (unpublished data, not shown), which, together with the Australian continent, makes this region the most diverse for these particular cestodes on a global scale (Schaeffner, 2013). Eutetrarhynchus beveridgei is also the thirteenth trypanorhynch species new to science reported from Borneo (see Schaeffner, 2013; Schaeffner et al., 2011; Schaeffner \& Beveridge, 2012a, b, c, 2013).

The extensive collecting effort in the Malaysian and Indonesian parts of Borneo also revealed the presence of a second species of Eutetrarhynchus, E. leucomelanus. The single worm was recovered from the spiral valve of Taeniura lymma 1 (BO-87) (sensu Naylor et al., 2012) obtained from a local fish market in Semporna, Sabah (Malaysian Borneo). Originally, $E$. leucomelanus was described from Dutch Bay, Sri Lanka (Shipley and Hornell, 1906) and it was later reported from Fog Bay, Australia (Beveridge, 1990). This distribution from the Laccadive Islands to the Timor Sea is now expanded to the Celebes Sea making E. leucomelanus a widespread but relatively rare parasite.

Acknowledgements The author is deeply indebted to his former supervisors Ian Beveridge and Robin B. Gasser (both University of Melbourne, UoM) for all their help and support throughout the course of the Ph.D. Sincere thanks are due to Janine N. Caira (University of Connecticut) and Kirsten Jensen (University of Kansas) for the collection of trypanorhynch material from Borneo and for providing it for the present and former studies. The author is also much obliged to Christine Andersen (UoM) for years of help and support and Joan Clark (Monash Micro Imaging) for her patience taking SEM micrographs of tiny tentacles. Collecting in Borneo was funded by the National Science Foundation (NSF) (BS\&I award No DEB 0103640; PBI award Nos 0818696 and 0818823). 


\section{References}

Beveridge, I. (1990). Taxonomic revision of Australian Eutetrarhynchidae Guiart (Cestoda: Trypanorhyncha). Invertebrate Taxonomy, 4, 785-845.

Beveridge, I., \& Jones, M. K. (2000). Prochristianella spinulifera n. sp. (Cestoda:

Trypanorhyncha) from Australian dasyatid and rhinobatid rays. Systematic Parasitology, $47,1-8$.

Beveridge, I., Neifar. L., \& Euzet, L. (2004). Eutetrarhynchid cestodes from Atlantic and Mediterranean elasmobranch fishes, with the description of two new species of Dollfusiella Campbell \& Beveridge, 1994 and redescriptions of Prochristianella papillifer (Poyarkoff, 1909) Dollfus, 1957 and Parachristianella trygonis Dollfus, 1946. Systematic Parasitology, 59, 81-102.

Caira, J. N., Jensen, K., \& Barbeau, E. (2012). Global Cestode Database. World Wide Web electronic publication. www.tape wormdb.uconn.edu. Accessed July, 2012.

Caira, J. N., Jensen, K., \& Holsinger, K. E. (2003). On a new index of host specificity. In: Combes, C., \& Jourdane, J. (Eds) Taxonomy, ecology, and evolution of metazoan parasites, Vol. 1. Perpignan: Presses Universitaires de Perpignan, pp. 161-201.

Campbell, R. A., \& Beveridge, I. (1994). Order Trypanorhyncha Diesing, 1863. In: Khalil, L. F., Jones, A., \& Bray, R. A. (Eds) Keys to the cestode parasites of vertebrates. Wallingford: Commonwealth Agricultural Bureaux International, pp. 51-148.

Campbell, R. A., F. Marques, \& Ivanov, V. A. (1999). Paroncomegas araya (Woodland, 1934) n. gen. et comb. (Cestoda: Trypanorhyncha: Eutetrarhynchidae) from the freshwater stringray Pomatotrygon motoro in South America. Journal of Parasitology, 85, 313-320.

Chervy, L. (2002). The terminology of larval cestodes or metacestodes. Systematic Parasitology, $52,1-33$.

Dollfus, R. P. (1942). Études critiques sur les Tétrarhynques du Muséum de Paris. Archives du Muséum National d'Histoire Naturelle, 19, 1-466.

Friggens, M. M., \& Duszynski, D. W. (2005). Four new cestode species from the spiral intestine of the round stingray, Urobatis halleri, in the northern Gulf of California, Mexico. Comparative Parasitology, 72, 136-149.

Haseli, M., Malek, M., \& Palm, H. W. (2010). Trypanorhynch cestodes of elasmobranchs from the Persian Gulf. Zootaxa, 2492, 28-48.

Last, P. R., White, W. T., Caira, J. N., Dharmadi, Fahmi, Jensen, K., Lim, A. P. K., ManjajiMatsumoto, B. M., Naylor, G. J. P., Pogonski, J. J., Stevens, J. D., \& Yearsley, G. K. (2010). Sharks and rays of Borneo. Collingwood: CSIRO Publishing, 298 pp. 
Naylor, G. J. P., Caira, J. N., Jensen, K., Rosana, K. A. M., White, W. T., \& Last, P. R. (2012). A DNA sequence based approach to the identification of shark and ray species and its implications for global elasmobranch diversity and parasitology. Bulletin of the American Museum of Natural History, 367, 1-262.

Palm, H. W. (2004). The Trypanorhyncha Diesing, 1863. Bogor: PKSPL-IPB Press, 710 pp.

Pintner, T. (1913). Vorarbeiten zu einer Monographie der Tetra-rhynchoideen. Sitzungsberichte der Kaiserlichen Akademie der Wissenschaften in Wien, MathematischNaturwissenschaftliche Klasse, 122, 171-253.

Schaeffner, B. C. (2013). Cestodes of the order Trypanorhyncha Diesing, 1863 from South-east Asia and Australia. PhD thesis, Faculty of Veterinary Science, The University of Melbourne, 414 pp.

Schaeffner, B. C., \& Beveridge, I. (2012a). Cavearhynchus, a new genus of tapeworm (Cestoda: Trypanorhyncha: Pterobothriidae) from Himantura lobistoma Manjaji-Matsumoto \& Last, 2006 (Rajiformes) off Borneo, including redescriptions and new records of Pterobothrium Diesing, 1850. Systematic Parasitology, 82, 147-165.

Schaeffner, B. C., \& Beveridge, I. (2012b). Description of a new trypanorhynch species (Cestoda) from Indonesian Borneo, with the suppression of Oncomegoides and the erection of a new genus Hispidorhynchus. Journal of Parasitology, 98, 408-414.

Schaeffner, B. C., \& Beveridge, I. (2012c). Prochristianella Dollfus, 1946 (Trypanorhyncha: Eutetrarhynchidae) from elasmobranchs off Borneo and Australia, including new records and the description of four new species. Zootaxa, 3505: 1-25.

Schaeffner, B. C., \& Beveridge, I. (2013). Dollfusiella Campbell \& Beveridge, 1994 (Trypanorhyncha: Eutetrarhynchidae) from elasmobranchs off Borneo, including descriptions of five new species. Systematic Parasitology, 86, 1-31.

Schaeffner, B. C., Gasser, R. B., \& Beveridge, I. (2011). Ancipirhynchus afossalis n. g., n. sp. (Trypanorhyncha: Otobothriidae), from two species of sharks off Indonesian and Malaysian Borneo. Systematic Parasitology, 80, 1-15.

Shipley, A.E. \& Hornell, J. (1906) Report on the cestode and nematode parasites from the marine fishes of Ceylon. In: Herdman, W.A. (Ed.) Report to the government of Ceylon on the Pearl Oyster Fisheries of the Gulf of Manaar, Part 5, London, pp. 43-96.

\section{Captions to figures}


Fig. 1 Line drawings of Eutetrarhynchus beveridgei n. sp. from Himantura walga (Müller \& Henle) (BO-141: B, C, E; BO-162: A, F; BO-238: D) in the South China Sea. A, scolex, lateral view; B, bulb; C, pars bothrialis, dorso-ventral view; D, detail of cirrus-sac, composite line drawing from serial sections; E, mature segment; F, outline of entire cestode. Abbreviations: c, cirrus; cs, cirrus-sac; isv, internal seminal vesicle; mg, Mehlis' gland; ov, ovary; t, testis; va, vagina; vit, vitelline follicle; vs, vaginal sphincter

Fig. 2 Line drawings of tentacular armature of Eutetrarhynchus beveridgei n. sp. from Himantura walga (Müller \& Henle) (BO-30: C; BO-162: A, B) in the South China Sea. A, basal tentacular armature, internal surface; B, metabasal tentacular armature, bothrial to external surface; $\mathrm{C}$, basal tentacular armature, antibothrial to external surface

Fig. 3 Scanning electron micrographs of Eutetrarhynchus beveridgei n. sp. from Himantura walga (Müller \& Henle) (BO-238) in the South China Sea. A, complete specimen, lateral view; $\mathrm{B}$, detailed view of pars bothrialis; $\mathrm{C}$, palmate spinitriches and acicular filitriches covering proximal bothrial surface; D, palmate spinitriches and acicular filitriches covering scolex peduncle; E, basal tentacular armature, bothrial surface; F, metabasal tentacular armature, external surface; G, metabasal tentacular armature, antibothrial surface; $\mathrm{H}$, metabasal tentacular armature, internal surface; I, metabasal tentacular armature, bothrial surface; J, metabasal tentacular armature, close-up on bothrial surface. Symbols: *, position on proximal bothrial surface where microthrix micrograph $(\mathrm{C})$ was taken; + , position on scolex peduncle where microthrix micrograph (D) was taken 


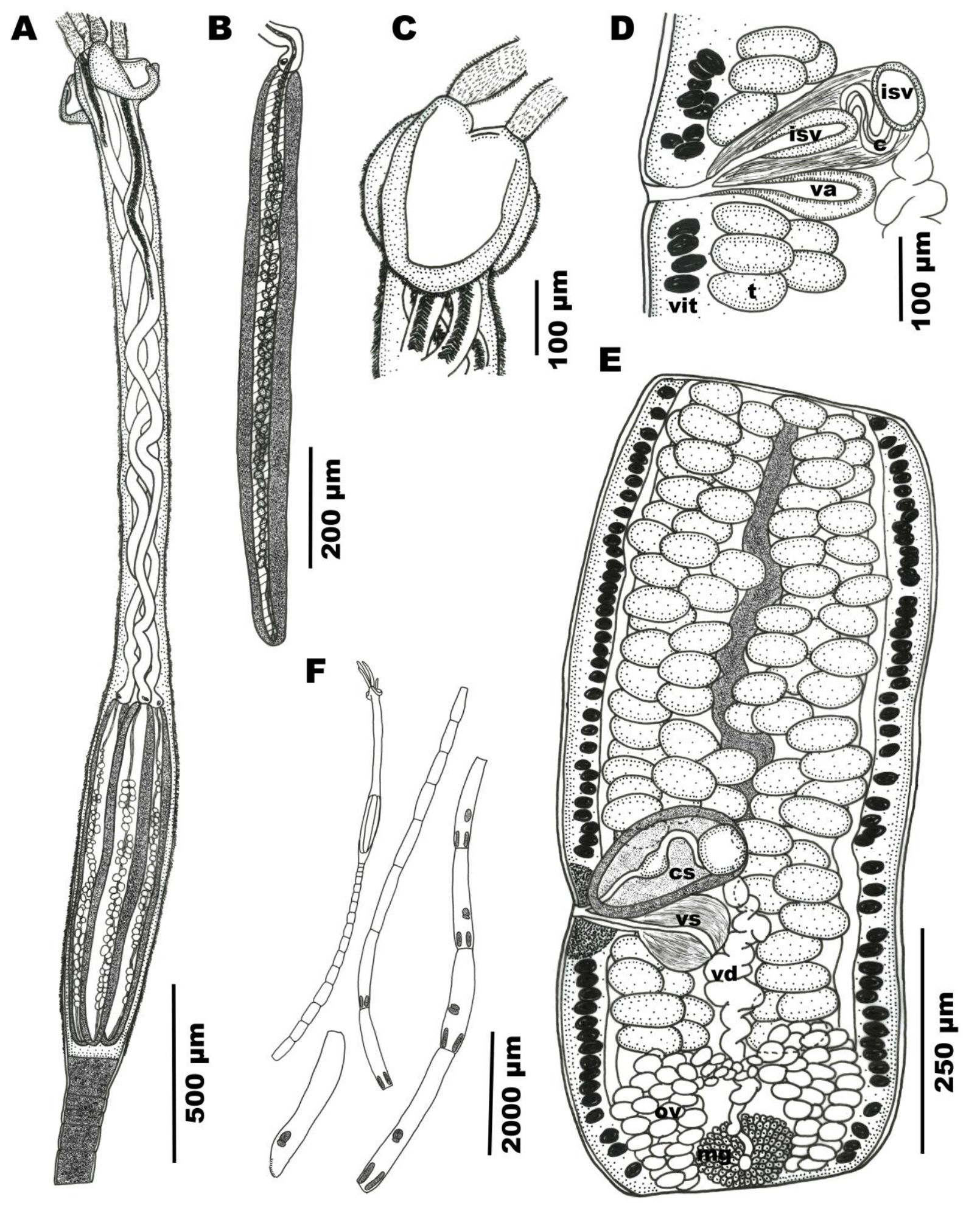




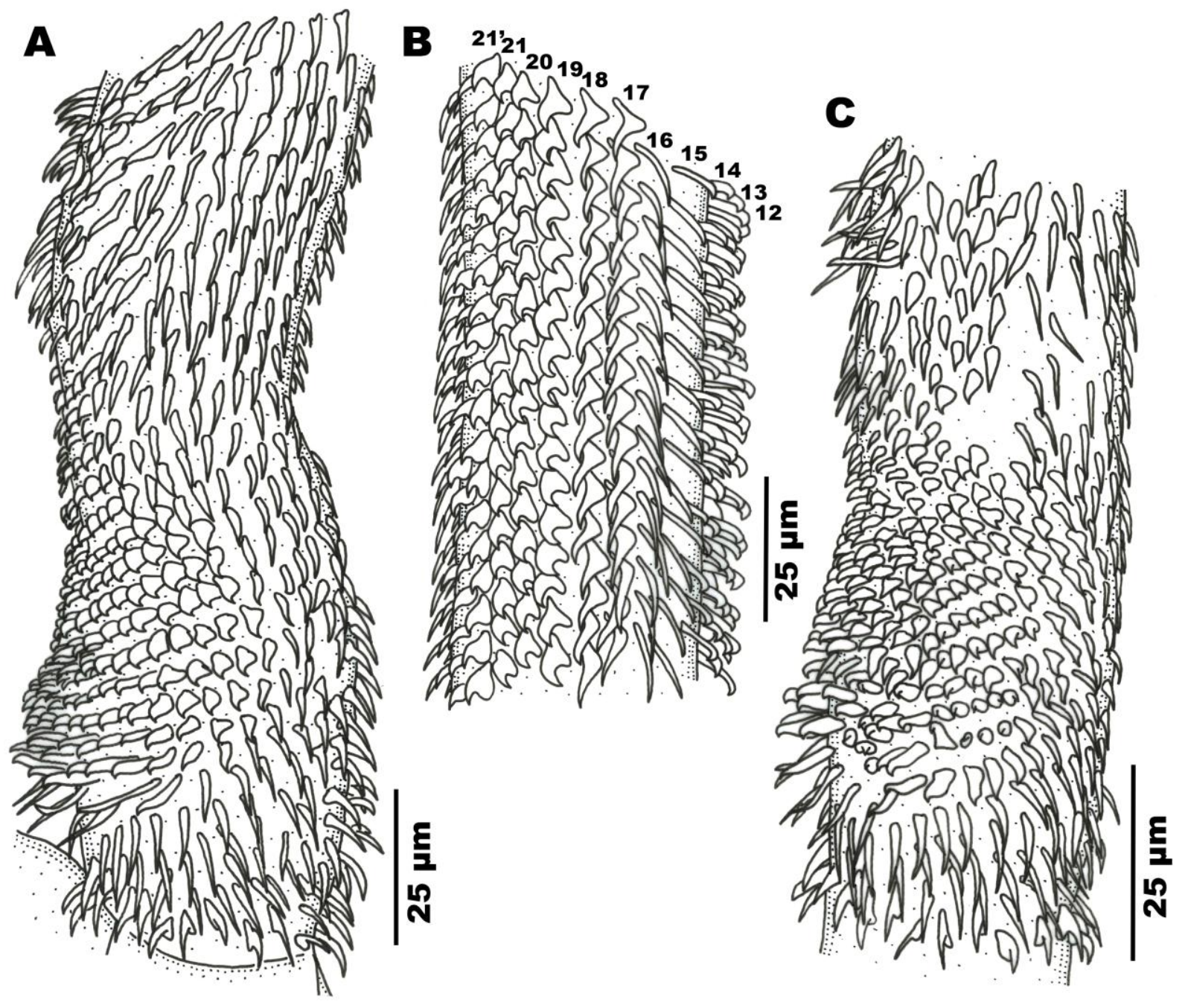




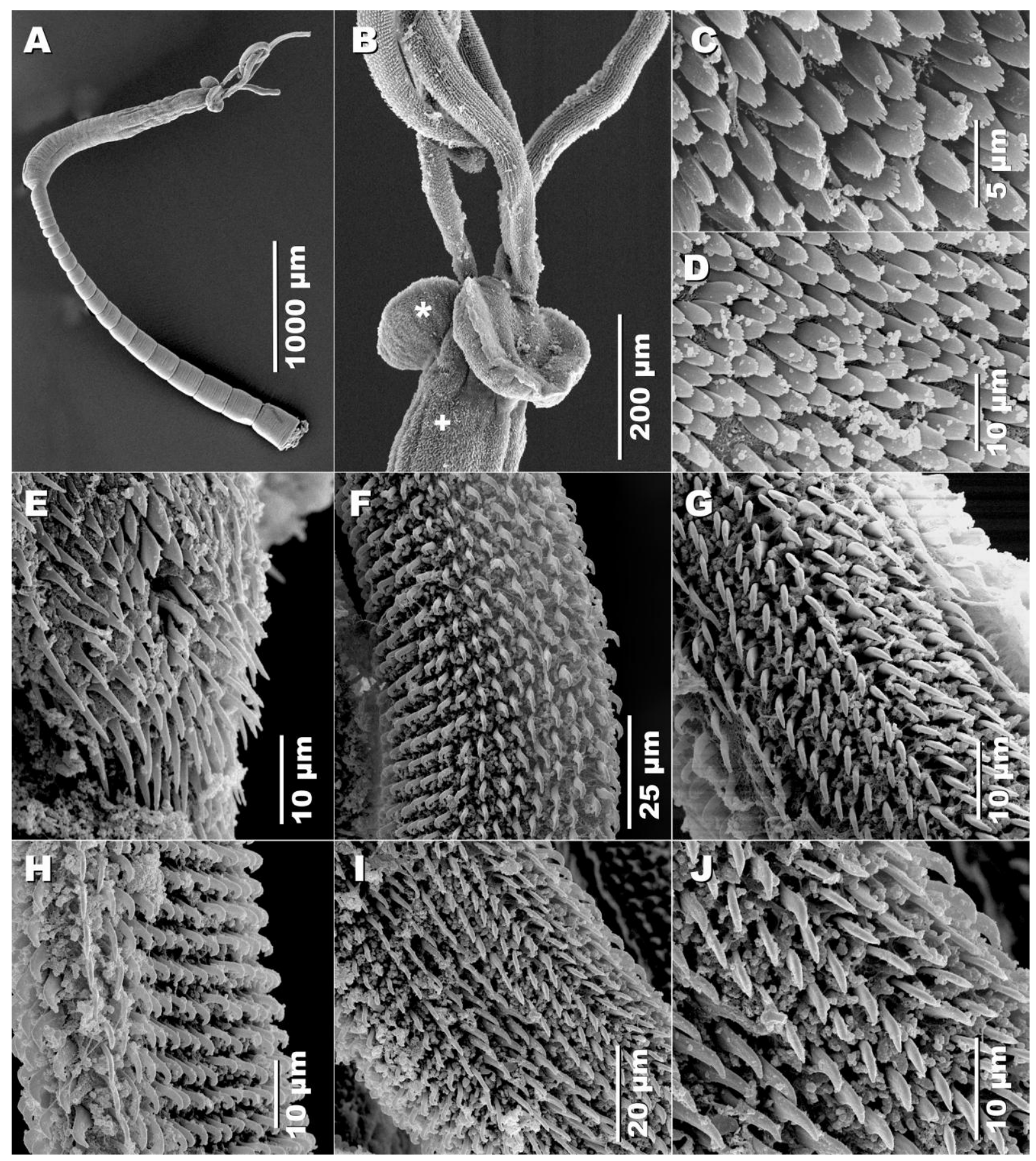




\section{University Library}

\section{- M M N E R VA A gateway to Melbourne's research publications}

Minerva Access is the Institutional Repository of The University of Melbourne

Author/s:

Schaeffner, BC

Title:

Review of the genus Eutetrarhynchus Pintner, 1913 (Trypanorhyncha: Eutetrarhynchidae), with the description of Eutetrarhynchus beveridgei n. sp.

Date:

2014-03-01

Citation:

Schaeffner, B. C. (2014). Review of the genus Eutetrarhynchus Pintner, 1913

(Trypanorhyncha: Eutetrarhynchidae), with the description of Eutetrarhynchus beveridgei

n. sp.. SYSTEMATIC PARASITOLOGY, 87 (3), pp.219-229. https://doi.org/10.1007/ s11230-014-9476-5.

Persistent Link:

http://hdl.handle.net/11343/282746 